\title{
Pengujian Efek Fisher Internasional: Studi Kasus Indonesia Dan China
}

\author{
(The Testing of International Fisher Effect : A Case Study of Indonesia and China) \\ Ernawati Nurul Hidayah, Zainuri ${ }^{1}$, Anifatul Hanim \\ Program Studi Ekonomi Pembangunan Fakultas Ekonomi dan Bisnis Universitas Jember \\ Jln. Kalimantan 37, Jember 68121 \\ *E-mail: aznrjbr@gmail.com
}

\begin{abstract}
Abstrak
Kemampuan Cina yang dapat mempengaruhi perekonomian secara global menempatkan China sebagai negara yang patut diperhitungkan dalam pengambilan kebijakan melalui variabel moneter. Tujuan penelitian ini adalah untuk mengetahui pengaruh jangka pendek dan jangka panjang selisih suku bunga Indonesia-China, selisih Inflasi Indonesia-China, dan nilai tukar yuan terhadap nilai tukar rupiah berdasarkan teori efek fisher internasional. Penelitian ini menggunakan metode Error Correction Model (ECM). Estimasi ECM jangka pendek menunjukkan bahwa hubungan antara selisih suku bunga, selisih inflasi, dengan nilai tukar rupiah tidak sesuai dengan teori efek fisher internasional karena memiliki hubungan yang positif dan tidak signifikan, sedangkan nilai tukar yuan sesuai dengan teori karena memiliki hubungan negatif. Selanjutnya hasil estimasi ECM jangka panjang menunjukkan adanya kesenjangan sehingga determinasi nilai tukar rupiah didomnasi oleh nilai tukar yuan. Hubungan antara selisih suku bunga dan selisih inflasi berlawanan dengan teori dan hanya variabel nilai tukar yuan memiliki hubungan dengan nilai tukar rupiah sesuai dengan teori efek fisher internasional.
\end{abstract}

Kata Kunci: teori efek fisher internasional, nilai tukar rupiah, suku bunga, inflasi, analisis error correction model (ECM).

\begin{abstract}
The fluctuation of rupiah exchange rate caused by the application of open economy system especially with China in ACFTA international organization, which has good economy and influences in global can draw China as the worthy country in takin the policy through monetary variables. The purpose of this research is to know the short term and long term influence of the differences in Indonesia-China interest, the differences of Indonesia-China inflation, and Yuan exchange rate to rupiah exchange rate based on international fisher effect theory. This research focuses on quantitative analysis by using Error Correction Model (ECM) method. Short term ECM estimation shows that the relation between differences of interest, differences of inflation with rupiah exchange rate is not suitable with international fisher effect theory because is has positive and insignificant relation, yuan exchange rate with rupiah exchange rate is suitable with theory because is has negative. Then, the result of short term ECM estimation shows that there is a gap so the determination of rupiah exchange rate is dominated by Yuan exchange rate. The relation between the difference of interest and the difference of inflation is contrary with the theory and it is only Yuan exchange rate that has the relation with rupiah exchange rate and it is suitable with international fisher effect theory.
\end{abstract}

Keywords: international fisher effect theory, rupiah exchange rate, interest, inflation, error correction model (ECM) analysis

\section{Pendahuluan}

Penerapan sistem perekonomian terbuka di Indonesia memberikan gambaran bahwa terdapat kerjasama ekonomi internasional yang dapat mempengaruhi kondisi ekonomi. Kerjasama tersebut salah satunya dengan melakukan kegiatan perdagangan internasional atau ekspor dan impor seperti yang dilakukan oleh Indonesia. Perdagangan internasional merupakan faktor penting dalam mendorong perekonomian karena dapat berdampak bagi perekonomian domestik, baik dampak positif maupun dampak negatif. Kerjasama internasional juga dapat menjadi ancaman karena dapat menimbulkan masalah yang disebabkan oleh perekonomian global, tetapi juga dapat bermanfaat karena dapat mencukupi kebutuhan masing-masing negara yang tidak dapat dipenuhi sendiri (Kemendag, 2011).

Kerjasama internasional menyebabkan Indonesia mengikuti beberapa organisasi perdagangan internasional seperti ASEAN dan ACFTA. ASEAN (Association of South East Asian Nation) merupakan organisasi internasional regional yang mempunyai eksistensi yang cukup diperhitungkan di tatanan internasional. Menciptakan integrasi ekonomi antar negara dikawasan Asia Tenggara merupakan salah satu fokus agenda ASEAN, dan salah satu usaha untuk mewujudkannya ialah melalui kerjasama perdagangan bebas. Perdagangan bebas merupakan salah satu bentuk kerjasama perdagangan oleh dua negara atau lebih untuk membentuk wilayah perdagangan bebas, sehingga perdagangan barang dan jasa antar negara dapat melewati perbatasan tanpa dikenakan hambatan tarif ataupun non tarif (Siwi, Tanpa tahun).

Penerapan perdagangan bebas yang dilakukan dengan negara kawasan ASEAN berkembang menjadi penerapan perdagangan bebas dengan negara diluar ASEAN seperti China, Jepang dan Korea Selatan. Namun, dari ketiga negara tersebut China menjadi sorotan utama ASEAN dalam penerapan perdagangan bebas karena China merupakan negara yang mempunyai kekuatan ekonomi yang patut diperhitungkan, hal ini yang mendasari dibentuknya ACFTA (ASEAN China Free Trade Area). ACFTA dibentuk untuk mewujudkan kawasan perdagangan bebas dengan mengurangi hambatan perdagangan baik tarif maupun nontarif, peningkatan akses pasar, peraturan dan ketentuan investasi, dan peningkatan aspek kerjasama ekonomi untuk

1 Corresponding Author 
mendorong hubungan perekonomian dalam rangka meningkatkan kesejahteraan masyarakat ASEAN dan China (Siwi, Tanpa tahun). Penerapan ACFTA berdampak negatif terhadap negatif terhadap perekonomian domestik karena perekonomian China lebih dominan dibandingkan dengan negara-negara ASEAN (Jurnal Sosial Demokrasi, 2010:17).

Indonesia dalam melakukan kegiatan perdagangan internasional mempunyai beberapa negara mitra utama dagang, antara lain Jepang, Singapura, China, Malaysia, dan Amerika (Kemendag, 2011). Namun, pada periode 2010 sampai 2014 China mendominasi menjadi negara tujuan ekspor dan impor Indonesia sehingga menjadi negara tujuan terbesar dari empat negara lainnya (Kemendag, 2015). Jumlah ekspor yang meningkat dapat meningkatkan surplus neraca perdagangan, tapi jika ekspor tertinggi pada salah satu negara tujuan ekspor dapat menyebabkan ketergantungan pasar dan dapat berpengaruh pada perekonomian domestik melalui variabel moneter. China sebagai negara tujuan utama ekspor Indonesia dapat berdampak negatif terhadap perekonomian domestik jika perekonomian China mengalami pelemahan. Dampak tersebut karena perekonomian China yang berpengaruh terhadap perekonomian global terutama pada negara mitra dagangnya.

China sebagai negara yang memiliki perekonomian yang kuat juga mengalami gejolak ekonomi, seperti perlambatan pada sisi permintaan dan sisi produksi. Perlambatan pada sisi permintaan berasal dari turunnya pertumbuhan konsumsi dan investasi. Perlambatan dari sisi produksi berasal dari sektor industri tersier, sehingga bank sentral China menerapkan kebijakan melalui reksasi aturan kredit rumah yang berlaku sejak awal oktober 2014. Potensi perlambatan ekonomi China yang terus berlanjut juga terindikasi dari masih besarnya downside risk pada sektor perumahan dan meningkatnya risiko deleveraging (Bank Indonesia, 2014).

Perlambatan perekonomian China berlanjut dengan ditandai melemahnya sektor perumahan yang berpengaruh pada pertumbuhan konsumsi baja dan aktivitas kontruksi. Sektor produksi manufaktur juga melemah yang ditandai dengan penurunan investasi aset tetap yang semakin dalam sementara indeks produksi menurun. Perlambatan ekonomi ditahan dengan upaya mencapai target pertumbuhan dengan menggunakan berbagai kebijakan pelonggaran. Namun, kebijakan pelonggaran masih terbatas sehingga pertumbuhan uang dan kredit masih rendah akibat beban utang dan leverage yang masih tinggi (Bank Indonesia, 2015).

Perekonomian China masih melemah ditengah tekanan pasar saham yang terus berlanjut. Sehingga untuk meningkatkan daya saing produk ekspornya bank sentral China melakukan devaluasi yuan dan merubah mekanisme penentuan nilai tukar yuan menjadi lebih market-driven, yang memberikan dampak tambahan resiko tekanan nilai tukar kepada mitra dagang China termasuk Indonesia. Ekspor China sedikit terdorong oleh kebijakan devaluasi yuan tapi masih tumbuh negatif akibat perlambatan ekonomi global. Pertumbuhan impor juga masih negatif karena harga impor yang lebih mahal di dorong oleh devaluasi yuan dan permintaan domestik. Dampak dari perlambatan perekonomian China serta kebijakan yang dilakukan bagi negara mitra dagang China seperti Indonesia adalah terdepresiasinya nilai tukar rupiah yang dapat berpengaruh pada perekonomian domestik (Bank indonesia, 2015), sehingga perekonomian China dapat menjadi pertimbangan pengambilan keputusan atau kebijakan di dalam negeri terutama tentang nilai tukar rupiah. Kebijakan dapat merupakan perpaduan dari pihak pemerintah dan Bank Indonesia untuk memperkokoh stabilitas makro ekonomi, yang bertumpu pada hubungan antara suku bunga dalam perekonomian peperti pengendalian inflasi dan nilai tukar (Bank Indonesia, 2014: Ascarya, 2012).

Fenomena yang menghubungkan nilai tukar luar negeri (yuan) dengan nilai tukar domestik (rupiah) berkaitan dengan suatu teori yaitu Teori Efek Fisher Internasional (IFE) yang mengkaji tentang hubungan antara tingkat bunga dengan nilai tukar mata uang asing. Teori IFE merupakan gabungan dari Teori Efek Fisher dan Teori Paritas Daya Beli (PPP). Lailatul Magfiroh (2013) pada penelitiannya mengatakan bahwa nilai tukar rupiah dideterminasi oleh variabel moneter yang terkait dekat dengan perdagangan internasional sesuai dengan teori IFE. Emil Sunqvist (2002) mengatakan bahwa teori IFE berlaku hanya pada periode waktu tertentu dan pada negara dengan kondisi tertentu pula. Penelitian ini ditujukan mengetahui perilaku suku bunga, inflasi, dan nilai tukar sesuai atau tidak dengan teori Efek Fisher Internasional tersebut, dan seberapa besar pengaruh nilai tukar yuan China terhadap dolar Amerika terhadap nilai tukar rupiah Indonesia.

\section{Metode}

\section{Rancangan atau Desain}

Penelitian ini menggunakan pendekatan deskriptif kuantitatif dengan dareah penelitian adalah Indonesia dan China. Fokus penelitian ini adalah mengetahui pengaruh masing-masing veriabel independen terhadap inilai tukar rupiah dalam jangka pendek dan jangka panjang.

\section{Jenis dan Sumber Data}

Jenis data berupa data sekunder merupakan data yang diperoleh secara tidak langsung. Sumber data penelitian berasal dari Bank Indonesia, Asean Development Bank dan institusi terkait lainnya. pengambilan periode 2007;Q3 sampai 2015;Q4 didasarkan pada keterbatasan data, di mana tahun 2007 merupakan tahun awal terjadinya krisis perekonomian dan 2008 merupakan dampak dari gejolak perekonomian global.

\section{Metode Analisis Data}

Metode analisis data yang digunakan adalah regresi model dinamis yaitu Error Correction Model (ECM) EngleGranger, dengan jumlah variabel empat yaitu nilai tukar rupiah, selisih suku bunga Indonesia-China, selisih inflasi Indonesia-China, dan nilai tukar yuan China. Tahapan analisis sebelum estimasi ECM yaitu dilakukan uji stasioneritas dan uji kontegrasi terlebih dahulu. Uji stasioneritas yaitu uji untukmenghindari regresi lancung, sedangkan uji kointegrasi yaitu uji untuk mengetahui model mempunyai keseimbangan jangka panjang (Widarjono, 2013). uji stasioneritas yang digunakan adaah uji Augmented Dickey Fuller (ADF) dan uji kointegrasi menggunakan uji kointegrasi Johansen.

Data setelah memenuhi syarat stasioneritas dan kointegrasi maka dapat dilakukan dengan analisis ECM. Estimasi ECM terdapat dua pendekatan yaitu pendekatan ECM jangka pendek dan ECM jangka panjang. Estimasi ECM jangka pendek dilakukan dengan menambah variabel error 
correction. Estimasi ECM dirumuskan sebagai berikut (Widarjono, 2013):

LLUPIAH $_{t}=a_{0}+a_{1} \Delta S S B_{t}+a_{2} \Delta S I_{t}+a_{3} \Delta L Y U A N_{t}+a_{4} E C_{t-1}$

sedangkan estimasi jangka panjang sebagai berikut:

LRUPIAH $_{t}=\beta_{0}+\beta_{1} S S B_{t}+\beta_{2} S_{t}+\beta_{3}$ LYUAN $_{t}$.

dimana LRUPIAH adalah nilai tukar rupiah; SSB adalah selisih suku bunga Indonesia-China; SI adalah selisih inflasi Indonesia-China.

Syarat estimasi ECM Engle-Granger yaitu nilai koefisien dan $\mathrm{t}$ statistik harus minus dan nilai probabilitas error correction signifikan. Estimasi data yang menggunakan data runtut waktu mengharuskan melakukan uji asumsi klasik. Uji asumsi klasik yang digunakan yaitu 1) uji multikolinieritas dengan melihat nilai dari correlation matrix. 2) uji autokorelasi dengan melihat probabilitas Chi-square uji Breusch-Godfrey (BG). 3) uji heteroskedastisitas dengan melihat nilai probabilitas Chi-square uji Breusch-PaganGodfrey. 4) uji normalitas dengan melihat nilai probalititas Jarque-Berra (JB).

\section{Hasil dan Pembahasan}

\section{Hasil}

Pengujian data dalam penelitian ini menggunakan analisis yaitu Error Correction Model (ECM) Engle-Granger jangka pendek dan jangka panjang. Sebelum dilakukan estimasi ECM dilakukan uji stasineritas dan uji kointegrasi. Berdasarkan hasil uji diketahui bahwa semua variabel telah stasioner dan berkointegrasi pada tingkat first different dengan tingkat kepercayaan 95\%. Kemudian dilanjutkan dengan estimasi ECM jangka pendek, uji asumsi klasik, dan estimasi ECM jangka panjang.

\section{Uji Stasioneritas Data}

Uji stasioneritas dilakukan dengan menguji setiap variabel melalui estimasi data dengan tingkat uji tertentu sampai data stasioner. Hasil estimasi uji akar-akar unit menunjukkan bahwa variabel tidak stasioner pada tingkat level karena nilai dari ADF lebih kecil dari nilai kritis MacKinnon dan nilai probabilitas ADF tidak signifikan. Nilai kritis dalam tingkat level yaitu $1 \%=-3.646342,5 \%=-2.954021,10 \%=-2.615817$. Hasil estimasi akar-akar unit yang menunjukkan stasioneritas data ditunjukkan dalam tabel berikut:

Tabel 1 Hasil Estimasi Uji Akar-akar Unit

\begin{tabular}{lllr}
\hline & \multicolumn{3}{c}{ Tingkat First Difference } \\
\cline { 2 - 4 } Variabel & ADF Stat. & Prob. ADF & Ket \\
\hline LRUPIAH & -4.632168 & 0.0008 & $*$ \\
SSB & -4.998096 & 0.0003 & $*$ \\
SI & -4.260522 & 0.0021 & $*$ \\
LYUAN & -3.240654 & 0.0267 & $*$
\end{tabular}

${ }^{\mathrm{x}}$ ) data tidak stasioner. ${ }^{*}$ ) data stasioner

Hasil estimasi menunjukkan bahwa semua variabel dalam penelitian ini yaitu variabel nilai tukar rupiah, selisih inflasi
Indonesia-China, selisih suku bunga Indonesia-China, dan nilai tukar yuan memiliki derajat keyakinan $1 \%, 5 \%$, dan $10 \%$, namun dalam penelitian ini menggunakan derajat keyakinan 5\%. Derajat keyakinan diperoleh dari estimasi pada tingkat first difference sehingga data semua variabel dapat dikatakan stasioner dan dapat dilakukan estimasi selanjutnya.

\section{Uji Kointegrasi}

Data yang telah stasioner kemudian dilanjutkan dengan uji yang akan melihat perilaku data atau pengaruh data dalam periode berjangka. Uji selanjutnya yang dilakukan adalah uji kointegrasi. Estimasi uji kointegrasi dilakukan dengan menggunakan uji Unrestriced Cointegration Rank Test (Trace dan Maximum Eigenvalue). Hasil estimasi uji kontegrasi ditunjukkan dapa tabel berikut:

Tabel 2 Hasil Estimasi Uji Kointegrasi

\begin{tabular}{lcc}
\hline \multicolumn{2}{c}{$\begin{array}{c}\text { Unrestriced Cointegration Rank } \\
\text { Test }\end{array}$} & Critical Value (5\%) \\
\hline Trace & 55.14278 & 47.85613 \\
& & \\
Maximum & 34.66617 & 27.58434 \\
Eigenvalue & &
\end{tabular}

Hasil estimasi menunjukkan nilai Trace statistik dan Maximum Eigenvalue lebih besar dibandingkan dengan nilai critical value. Besaran nilai perbandingan tersebut yaitu 55.14278 lebih besar dari 47.85613 dan 34.66617 lebih besar dari 27.58434. hasil tersebut menunjukkan bahwa terdapat derajat kointegrasi atau keseimbangan jangka panjang pada variabel-variabel yang digunakan dalam penelitian.

\section{Estimasi ECM Jangka Pendek}

Hasil estimasi ECM dapat diketahui dari perbandingan tstatistik dan t-tabel yang dihubungkan dengan nilai koefisien tiap variabel independen terhadap variabel dependen. Hasil estimasi juga dapat diketahui dan diinterprestasikan dengan nilai adjusted $\mathrm{R}$-square, probabilitas F-statistik, dan nilai EC (error correction term). Nilai dari perbandingan hasil estimasi terhadap koefisien variabel dapat menunjukkan hubungan pengaruh antar variabel independen terhadap variabel dependen secara bersama-sama.

Tabel 3 Hasil Estimasi Jangka Pendek

\begin{tabular}{lccl}
\hline Variabel & Koefisien & t-Statistik & Prob. \\
\hline C & 0.008934 & 1.044292 & 0.3053 \\
DSSB & 0.055348 & 2.925588 & 0.0067 \\
DSI & 0.004388 & 0.795551 & 0.4330 \\
DLYUAN & -0.019478 & -0.028001 & 0.9779 \\
EC & -0.221153 & -1.861137 & 0.0728 \\
Ad. R-Square & & 0.368773 & \\
Prob. F-Sta & & & \\
T-tabel: $\alpha: 5 \%=1.660$ & 0.001787 & \\
\hline
\end{tabular}


Variabel selisih inflasi Indonesia-China dan nilai tukar yuan China tidak berpengaruh signifikan karena memiliki nilai probabilitas yang lebih besar dari 0,05 yaitu 0.4330 dan 0.9779. Hasil estimasi menunjukkan hubungan yang positif antara variabel selisih suku bunga dan selisih inflasi dengan nilai tukar rupiah, dan hubungan positif antara nilai tukar yuan dengan nilai tukar rupiah karena memiliki nilai koefisien yaitu $0.055348,0.004388$, dan -0.019478 .

\section{Uji Asumsi Klasik}

Hasil estimasi data variabel penelitian menunjukkan bahwa hasil pengujian menghasilkan diagnosa positif pada semua uji asumsi klasik. Uji asumsi klasik yang dilakukan dengan beberapa tahapan uji memberikan gambaran bahwa terdapat variabel yang tidak perlu ada perbaikan. Hasil estimasi beberapa uji asumsi klasik dijelaskan dalam tabel berikut:

Tabel 4 Hasil Estimasi Uji Asumsi Klasik

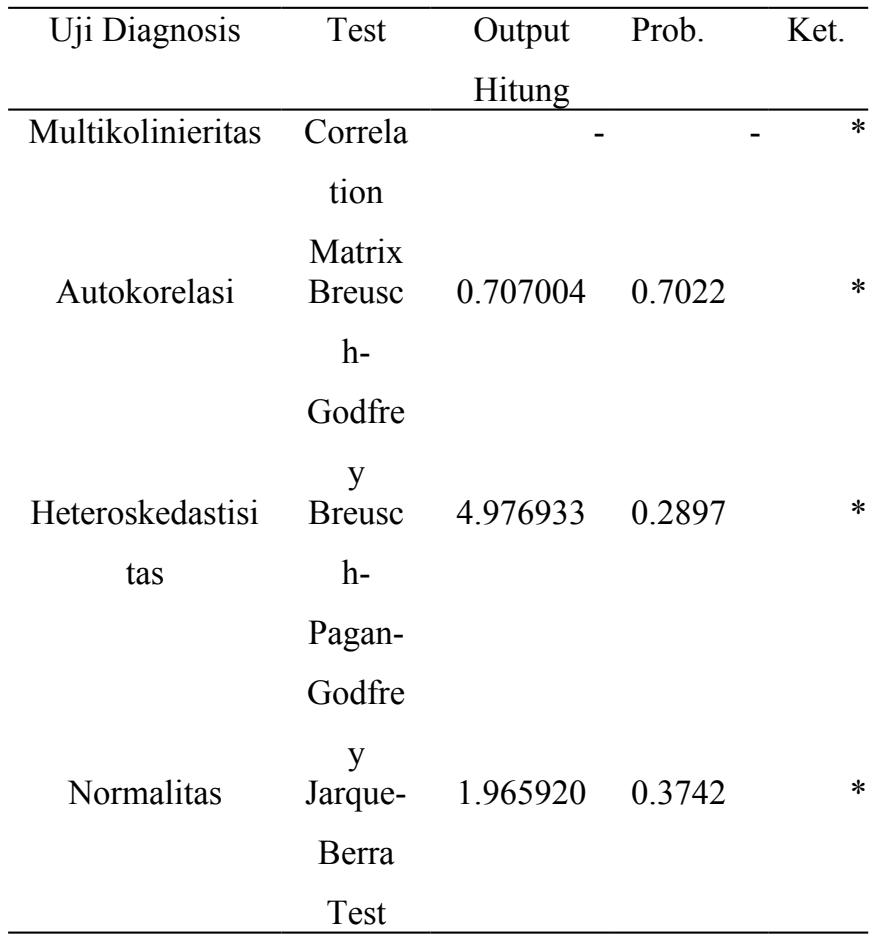

*) data lolos asumsi klasik, **) data tidak lolos asumsi klasik

\section{Estimasi ECM Jangka Panjang}

Hasil estimasi jangka panjang menunjukkan bahwa hanya dua dari tiga variabel independen yang berpengaruh signifikan terhadap variabel dependen. Variabel selisih suku bunga Indonesia-China berpengaruh positif dan signifikan terhadap nilai tukar rupiah dengan nilai koefisien sebesar 0.137378 dan probabilitas sebesar 0.0000 lebih kecil dari 0,05. Hasil estimasi ECM jangka panjang dijelaskan dalam tabel berikut:

Tabel 5 Hasil Estimasi Jangka Panjang

\begin{tabular}{lccl}
\hline Variabel & Koefisien & t-Statistik & Probabilitas \\
\hline C & 21.37885 & 9.982177 & 0.0000 \\
SSB & 0.137378 & 6.810740 & 0.0000 \\
SI & -0.003636 & -0.519534 & 0.6072 \\
LYUAN & -1.400986 & -5.749111 & 0.0000
\end{tabular}
Ad.R-square
0.765291
Prob. F-Sta
0.000000

Nilai tukar yuan China berpengaruh negatif dan signifikan terhadap nilai tukar rupiah dengan koefisien sebesar -1.400986 dan probabilitas sebesar 0.000 lebih kecil dari 0.05. Selisih inflasi Indonesia-China tidak berpengaruh signifikan karena memiliki nilai probabiitas sebesar 0.6072 lebih besar dari 0.05 , dan memiliki hubungan yang negatif dengan nilai tukar karena memiliki koefisien bertanda negatif yaitu sebesar -0.003636 .

\section{Pembahasan}

Pergerakan nilai tukar rupiah dipengaruhi oleh variabel moneter dalam negeri dan luar negeri berkaitan dengan fenomena dalam teori efek fisher internasional. Variabel moneter tersebut dalam penelitian ini diantaranya selisih suku bunga Indonesia dan China, inflasi Indonesia dan China, dan nilai tukar yuan China. Pengaruh luar negeri terjadi karena adanya hubungan kerjasama internasional. Indonesia menjalin kerjasama dengan China dalam salah satu organisasi internasional yaitu ACFTA. Berdasarkan teori efek fisher internasional perbedaan suku bunga yang besar atau tingkat suku bunga Indonesia lebih tinggi menyebabkan mata uang rupiah akan terdepresiasi, karena suku bunga merupakan cerminan dari perbedaan tingkat inflasi. Suku bunga dan inflasi Indonesia lebih tinggi dari China sehingga memenuhi syarat untuk terjadinya fenomena dalam teori efek fisher internasional.

Selisih suku bunga Indonesia-China dalam jangka panjang dan jangka pendek menunjukkan pola yang sama. Selisih suku bunga memiliki hubungan positif signifikan dalam jangka pendek dan jangka panjang. Pola hubungan tersebut tidak sejalan dengan teori efek fisher internasional karena teori menjelaskan bahwa nilai tukar akan berubah denganpersentase yang sama, tetapi arah berlawanan dengan perbedaan atau selisih tingkat suku bunga antara kedua negara (Hady, 2005). Hubungan positif antara selisih suku bunga dengan nilai tukar rupiah dalam kasus dapat dilihat dari perkembangan suku bunga dalam negeri dengan nillai tukar rupiah, ketika suku bunga mengalami penurunan perkembangan nilai tukar menunjukkan depresiasi (Bank Indonesia, 2015).

Selisih inflasi Indonesia-China dalam jangka panjang dan pendek menunjukkan pola hubungan yang berbeda meskipun tidak signifikan. Selisi inflasi dalam jangka pendek menunjukkan pola hubungan yang positif, sedangkan dalam jangka panjang menunjukkan pola hubungan yang negatif terhadap nilai tukar rupiah. Pola hubungan positif dalam jangka pendek menunjukkan tidak sejalan dengan teori efek fisher internasional, sedangkan dalam jangka panjang menunjukkan pola hubungan yang sesuai dengan teori. Perbedaan tersebut disebabkan karena dalam jangka pendek perdedaan inflasi tidak begitu besar antar kedua negara, sedangkan dalam jangka panjang perbedaan inflasi menunjukkan semakin besar karena nilai inflasi China yang semakin menurun sampai tahun 2015 dibandingkan nilai inflasi yang meningkat sampai tahun 2015 (Bank Indonesia, 2015; Trading Economics, 2015).

Nilai tukar yuan dalam jangka pendek dan jangka panjang menunjukkan pola hubungan yang sama tetapi signifikasi yang berbeda terhadap nilai tukar rupiah. Nilai tukar yuan 
memiliki hubungan negatif terhadap nilai tukar rupiah tetapi tidak berpengaruh signifikan dalam jangka pendek dan signifikan dalam jangka panjang. Yuan dalam jangka pendek tidak berpengaruh signifikan karena depresiasi rupiah tidak hanya dipengaruhi oleh yuan. Namun, dalam jangka panjang yuan berpengaruh signifikan yang berarti bahwa apresiasi nilai tukar yuan dapat menyebabkan depresiasi bagi nilai tukar rupiah dan begitu juga sebaliknya. Hal ini dibuktikan bahwa devaluasi nilai tukar yuan China terhadap dolar Amerika mengakibatkan gejolak keuangan global sehingga berdampak pada nilai tukar rupiah terhadap dolar Amerika (Lembaga Penjamin Simpanan, 2015).

Selisih inflasi dalam jangka pendek dan jangka panjang tidak berpengaruh signifikan, sedangkan yuan dalam jangka pendek tidak berpengaruh signifikan. Hal ini disebabkan karena inflasi Indonesia tidak selalu lebih besar dari China, dan depresiasi nilai tukar rupiah tidak hanya disebabkan oleh selisih inflasi dan yuan tetapi juga oleh kondisi dari sektor riil dalam negeri, defisit transaksi berjalan, pengaruh dari aliran masuk modal asing, kondisi politik dalam negeri, dan antisipasi investor terhadap rencana kenaikan suku bunga AS (Kompas, 2015, Bank Indonesia, 2013, Bank Indonesia, 2014, Bank Indonesia, 2015).

Hasil yang tidak sesuai dengan teori sejalan dengan penelitian Khawagu et al (2014) yang menyatakan bahwa tidak ada hubungan yang sesuai teori efek fisher internasional antara pound mesir dengan mata uang euro karena kondisi dalam negeri seperti sektor makro yang tidak seimbang, nilai tukar yang tidak diimbangi dengan perbedaan perbedaan suku bunga, dan keterbatasan integrasi keuangan Mesir dengan pasar keuangan internasional.

Penelitian ini sejalan dengan penelitian Magfiroh (2013) yang menyatakan bahwa inflasi, suku bunga, dan nilai tukar luar negeri sesuai dengan teori efek fisher internasional secara parsial. Selain itu, beberapa peneliti berpendapat hal yang sama seperti Elizadeh et al (2004), Sundqvist (2002), dan Shalishali (2012) yang menyatakan bahwa teori efek fisher internasional hanya berlaku untuk negara dengan kondisi perekonomin tertentu dan dalam kurun waktu tertentu. Hal ini sependapat dengan Khawagu et al (2014) yang menyatakan bahwa teori efek fisher internasional hanya berlaku pada nilai tukar pound mesir dan dolar Amerika tetapi tidak sesuai pada pound mesir dan mata uang eoru, dan Ersan (2008) yang menyatakan bahwa teori efek fisher internasional berlaku pada Perancis dan Jerman pada periode tertentu.

\section{Simpulan}

Penelitian ini bertujuan mengetahui pengaruh jangka pendek dan jangka panjang dari variabel selisih suku bunga Indonesia-China, selisih inflasi Indonesia-China, dan nilai tukar yuan terhadap nilai tukar rupiah berdasarkan teori efek fisher internasional, dan dengan metode error correction model (ECM). Hasil estimasi kuantitatif dengan metode ECM menunjukkan bahwa nilai tukar yuan China berhubungan negative dengan nilai tukar rupiah sehingga sesuai dengan teori sesuai dengan teori efek fisher internasional meskipun tidak berpengaruh signifikan. Namun, dalam jangka panjang nilai tukar yuan sesuai dengan teori karena memiliki hubungan negatif dan signifikan terhadap nilai tukar rupiah.
Selisih suku bunga Indonesia-China dalam jangka pendek dan jangka panjang menunjukkan hasil yang sama. Selisih suku bunga menunjukkan hasil yang tidak sesuai dengan teori efek fisher internasional karena memiliki hubungan yang positif terhadap nilai tukar rupiah. Hal ini disebabkan karena nilai tukar rupiah tidak hanya dipengaruhi suku bunga dan suku bunga Indonesia tidak selalu lebih besar dari China.

Selisih inflasi Indonesia-China menunjukkan polayang berbeda dalam jangka pendek dan jangka panjang. Selisih inflasi dalam jangka pendek tidak berpengaruh signifikan dan mempunyai hubungan yang positif dan nilai tukar sehingga tidak sesuai dengan teori efek fisher internasional. Namun, dalam jangka panjang selisih inflasi memiliki hubungan negatif terhadap nilai tukar sesuai dengan teori tetapi tidak berpengaruh signifikan.

\section{Ucapan Terima Kasih}

Penulis mengucapkan terima kasih kepada Direktorat Pendidikan Tinggi, Departemen Pendidikan dan Kebudayaan Republik Indonesia yang telah memberikan dukungan finansial melalui Beasiswa Bidik Misi tahun 2012-2016.

\section{Referensi}

Ersan, Eda. 2008. International Fisher Effect: A Reexamination Within The Co-Integration And Dsur Frameworks. Tesis. Middle East Technical University

Hady, Hamdy. 2005. Manajemen Keuangan Internasional. Jakarta. Yayasan Administrasi Indonesia

Maghfiroh, Lailatul. 2013. Pengujian Teori Efek Fisher Internasional Terhadap Nilai Tukar: Studi Kasus Indonesia-Jepang. Ilmu Ekonomi Dan Studi Pembangunan Universitas Jember

Widarjono, Agus. 2013.Ekonometrika Pengantar dan Aplikasi. Yogyakarta. UPP STIM YKPN

Bank Indonesia. 2015. Tinjauan Kebijakan Moneter september 2015

Engle, Robert F. Dan C. W. J. Granger. 1987. Co-Integration And Error Correction: Representation, Estimation, And Testing. Journal Econometrica, Vol 55, No. 2

Federasi Serikat Pekerja Metal Indonesia. 2010. Perdagangan Bebas ASEAN-Cina: Berdagang Untuk Siapa?. Jurnal Sosial Demokrasi,Vol. 8 No.3

Khawagu, Abla El, et al. 2014. Exchange Rates and Interest Rates: An Empirical Investigation of International Fisher Effect Theory - The Case of Egypt (2003-2012). Journal economic

Lembaga Penjamin Simpanan. 2015. Perekonomian dan Perbankan.

Republik Indonesia. 2011. Nota Keuangan dan Rancangan Anggaran Pendapatan dan Belanja Negara Perubahan.

Siwi, Arisa Permata. Tanpa Tahun. Hubungan Perdagangan IndonesiaChina dalam Kerangka ACFTA. Departemen Hubungan Internasional Universitas Erlangga

Sundqvist, Emil. 2002. An Empirical Investigation of the International Fisher Effect. Lulea University of Technology

Asian Development Bank. 2016. Asia Regional Integration Center. https://aric.adb. org/macroindicators/userdefined. [diunduh 7 Februari 2016]

Bank Indonesia. 2016. Laporan Inflasi (Indeks Harga Konsumen). http://www.bi.go. $\mathrm{id} / \mathrm{id} / \mathrm{moneter} /$ inflasi/data/Default.aspx. [diunduh 7 Februari 2016]

Bank Indonesia. 2016. BI Rate. $\leq$ http://www.bi.go.id/id/moneter/birate/data/Default. aspx. [diunduh 7 Februari 2016>]

Bank Indonesia. 2016. Kurs Referensi Jakarta Interbank Spot Dollar Rate (JISDOR). $\quad \leq$ http://www.bi.go.id/id/moneter/informasi-kurs/referensijisdor/ Default.aspx $>$. [ diunduh 7 Februari 2016] 